Gala Naseva

\section{The Chasm of Structural Discrimination: Women on the Frontline Against COVID-19}

Bionote: Gala Naseva (1992, Skopje) is a legal researcher and interdisciplinary artist. She is currently the main editor of the multilingual Association of Young journalists from the Balkans Platform. Naseva completed her LLM in Intellectual Property Law at CEIPI, Strasbourg University and is now finishing the MA program in Gender Studies at ISSHS, North Macedonia. She was a visiting student at Justus Liebig University, Germany (Applied Theatre Studies and Musicology departments). Naseva worked as a legal consultant for the Helsinki Committee of Human Rights, USAID, The National Democratic Institute and OSCE (ODIHR). She has been engaged in the process of harmonizing various domestic legal acts with EU legislation.

\section{Researcher \\ galanaseva@gmail.com}

Abstract: The swift and unceasing spread of COVID-19 has created a new wave of complications that have revealed dozens of issues dishevelled in the gendered and obsolete state management and in the low levels of social development, primarily focusing on the Balkans. With the onset of the pandemic, women with specific diseases belong to the most critical group, given the fact that infection with COVID-19 itself increases the risk of subsequent development of numerous health complications. This text briefly highlights the negative effects of the pandemic on women from several perspectives, trying to fleetingly show its severe impact on a global level and the necessity to improve a system that is barely surviving on already unsteady grounds.

Keywords: global crisis, women, COVID-19, gender-based discrimination, healthcare system

\section{Introduction}

As the progression of the pandemic started to become more evident, the sudden shift away from our ordinary and continuous social functioning, our communication with one another, has been altered immensely-its turnaround point started to emerge on the surface when distance became the most vital element of our day-today reality. All of the ongoing changes in terms of the restrictions of movement ${ }^{1}$ due to COVID-19, some of them unprecedented, led to many variations of mutual communication, and by that, left each individual in a state of oblivion that has rapidly spread throughout the globe, just as the pandemic started to fill out all spheres of society. The way we preserve the environment, as well as the continuous alterations of our segregated society, are both indispensable and key factors of the resilience of urbanized areas globally, reminding state executives that the long-awaited preparation for emergencies that are directly and inevitably caused by climate change-such as abrupt alterations in air, heat and pollution-are clearly needed. The emergence of COVID-19 reopened an ongoing and relevant discourse regarding the inequalities that occur due to gendered politics and underdeveloped state institutions, primarily showing the economic impact it has on women on a global level.

The COVID-19 regulations do not have the same impact on all citizens, since the structures of society continue to place a vast number of citizens on the margins, and even during these times when the pandemic is restlessly spreading, some people do not have the resources nor the opportunities to access basic health care. The United Nations' 2020 policy brief ${ }^{2}$ clearly states the reasons why women, in particular, are being struck by the pandemic more than men, considering the amount of pre-existing inequalities in different spheres, starting from economic independence, unpaid or underpaid care work, accessibility to health care and violence solely based on their gender. Additionally, women who are part of marginalized societies in underdeveloped countries are at an even higher risk of COVID-19 transmission and fatalities, loss of livelihood, and increased violence, according to the UN's latest report. Taking that

${ }^{1}$ World Aware, "COVID-19 Alert: European Countries Maintaining Movement \& Business Restrictions as of May," World Aware (May 20, 2020), https://www.worldaware.com/covid-19alert-european-countries-maintaining-movement-business-restrictions-may-20.

2United Nations, "Policy Brief: The Impact of COVID-19 on Women," Relief Web (April 9, 2020), https://reliefweb.int/sites/reliefweb.int/files/resources/policy-brief-the-impact-of-covid-19-onwomen-en.pdf. 
into consideration, the other part of the story is also causing a global concern, considering that approximately $70 \%$ of health workers and first responders around the globe are women, but they are still not on par economically with their male counterparts. "At $28 \%$, the gender pay gap in the health sector is higher than the overall gender pay gap (16\%)." ${ }^{4}$ Reconstructing the idea of young women as primary caretakers is profoundly entwined in the historical context of the society, in reciprocity with the influence from international bodies and communities that tend to create collective consciousness or unconsciousness, depending which societal group is primarily struck by the exploitation narrative. The ongoing impartial improvement in critical social spheres in the Western Balkan countries in the last five to ten years should not be professed nor confused for complete societal growth, considering the omnipresence of the out-of-date labour dichotomy and its incessant prevalence in Eastern European countries. Five long and rather painful economic fluctuations had struck the Western Balkans in the past and worsened the state of vulnerability that goes hand-by-hand with the long periods of transition, affecting the most valuable social spheres and causing a major setback to our already shaky economies, affecting the human capital and taking away already existing resources. ${ }^{5}$ Walking on already shaky grounds means that a crisis that presents itself as a heavy burden on a global level can only have an even more concerning negative impact on countries that are still coping with high percentage of poverty, gender inequality and unsteady economic structures, meaning that the multi-generational element of the family kinship that prevails in the Western Balkans has once again struck its most vulnerable members - women. ${ }^{6}$ Appraised as being primary care-takers, as if care for the youngest and the elderly family members is a freight to be carried around on their shoulders only, women are now facing a vast amount of newly presented issues that

${ }^{3}$ UN Women, "COVID-19 and its Economic Toll on Women: The story Behind the Numbers," UN Women (September 16, 2020), https://www.unwomen.org/en/news/stories/2020/g/featurecovid-19-economic-impacts-on-women.

${ }^{4}$ Ginette Azcona and Antra Bhatt, "From Insights to Action: Gender Equality in the Wake of COVID-19" (2020), https://www.unwomen.org/en/digital-library/publications/2020/og/genderequality-inthe-wake-of-covid-19.

${ }^{5}$ European Commission, "The Western Balkans in Transition," Occasional Papers 46 (May, 2009), https://ec.europa.eu/economy_finance/publications/pages/publication15155_en.pdf.

${ }^{6}$ Daša Šašić Šilović, "One Virus, Diverse Impacts: The Pandemic and Women in Central and Eastern Europe," Social Europe (July, 2020), https://www.socialeurope.eu/one-virus-diverseimpacts-the-pandemic-and-women-in-centraland-eastern-europe.

https://www.socialeurope.eu/one-virus-diverse-impacts-the-pandemic-and-women-in-centraland-eastern-europe keep on strolling along the pandemic-more women are pushed into poverty than men, the education gap is once again increasing and leaving young women without proper education, there is a disproportionate increase in women's unemployment which is later affecting their overall working time by significantly decreasing it. ${ }^{7}$

Although all of the countries in the Western Balkans had gone through many painful transformations and deliberate alterations in their socio-democratic core, from 2006 up to late $2016,{ }^{8}$ the principal wave of liberation has not managed to crucially transform the political articulation of valuable questions, such as the exploitation of marginalized communities. This has caused a very strange political discourse, one that presents an improved surface but which remains unchanged in regards to its, what we could call, profoundly ruined core values and fundamental principles of the rule of law, human rights and gender equality. ${ }^{9}$ The Western Balkans have already gone through significantly

\section{Cancer treatment during COVID-19}

Due to the specificity of the virus and its way of progression, from the very beginning of the pandemic, especially during the 24/7 quarantine in North Macedonia, there was a complete cessation of numerous interventions and diagnostic procedures that were regularly performed in health institutions. With the onset of the coronavirus pandemic, people with malignancies belong to one of the most critical groups, given the fact that COVID-19 itself increases the risk of subsequent developments of numerous health complications. In addition to that the consistent downfall of the number of healthcare workers in the country ${ }^{10}$ is also worsening the ongoing crisis, diminishing the institutional capacity to cope with the burden that inevitably started to present itself while the number of people that were struck by the virus was (and still is) growing As it has already been pointed out a few times in the past, "there's no such thing as a "spare" doctor," ${ }^{11}$ especially not since the pandemic began, when UN Women, "COVID-19 and its Economic Toll on Women: The story Behind the Numbers," UN Women (September 16, 2020), https://www.unwomen.org/en/news/stories/2020/9/featurecovid-19-economic-impacts-on-women.

${ }^{8}$ Elizabeta Miloshevska, "Faithful Elections in Macedonia," Deutsche Welle (December 09, 2020), https://www.dw.com/en/fateful-elections-in-macedonia/a-36711063.

9 United Nations, Universal Declaration of Human Rights (1948).

${ }^{10}$ Mirjana Spasovska, "Doctors Continue to Leave Macedonia," Radio Free Europe (August, 2018), https://www.slobodnaevropa.mk/a/29354761.html.

${ }^{11}$ Zaria Gorvett, "Why Most COVID-19 Deaths Won't be from the Virus", BBC (May, 2020), 
healthcare workers primarily focused on the successful reduction of the ponderous burden that a novel and unpredictable disease such as COVID-19 carries around. Globally, its heavy toll on medical facilities and personnel was immediately causing a bigger, and in a way insurmountable issue-one that can be easily noticed in the lack of availability of healthcare workers that can take and later process smear tests, do cancer screenings or help people at immediate risk. A vast amount of cancer screening programmes are currently paused across the U.K. since the beginning of the pandemic lockdowns, and this led to the incapability of healthcare workers to detect approximately 1,60o cancer cases on a monthly basis. Some diseases, such as cancer, are not going to respond well if put on hold, considering that an early diagnosis means easier and more successful treatment in most cases.

According to one of the latest cancer studies by The European Organization for Research and Treatment of Cancer, 31\% of women were less likely to seek help from their GP, $27 \%$ were worried about the effects of the pandemic on their aftercare and $15 \%$ were less likely to seek help from their breast cancer physician. In addition, it was concluded, as expected, that support will be restricted because of the continuous measures on social distance and long periods of quarantine. The study showed that women are generally less likely to ask for medical help or assistance during the coronavirus pandemic, and a bigger percentage of women started to develop symptoms that are generally connected to to depression and anxiety. Consequently, the results show that a lot of women-patients simply need reassurance or support to freely reach for medical aid, meaning that this missing link is what would enable them to receive proper mental health support. ${ }^{12}$

According to the research conducted by Globocan in 2018, ${ }^{13}$ there were about 1200 newly diagnosed cases per year in North Macedonia, and an average of twenty two people per day are about to be diagnozed with cancer. Due to the dangers that patients may face

https://www.bbc.com/future/article/20200528-why-most-covid-19-deaths-wont-be-from-thevirus.

${ }^{12}$ Claudia Bargon, "New Research Reveals Effects of COVID-19 on Breast Cancer Screening,

Treatment and Care," EurekAlert! (September 30, 2020), https://www.eurekalert.org/pub_ releases/2020-og/eofr-nrrog2920.php.

${ }^{13}$ International Agency for Research on Cancer, "The Former Yugloslav Republic of Macedonia 2018," Globocan (2018), https://gco.iarc.fr/today/data/factsheets/populations/807-theformeryugoslav-republic-of-macedonia-fact-sheets.pdf. during the pandemic, on April 11 this year, the Ministry of Health, in accordance with the University Clinic for Radiotherapy and Oncology, publicly announced the recommendations for people suffering from cancer:

University Clinic for Radiotherapy and Oncology informs patients that the institution operates smoothly and in conditions of COVID-19, due to the specificity of malignant diseases. Patients receiving chemotherapy and immunotherapy should call for regular appointments, as well as patients receiving radiotherapy. At the same time, it is recommended that the tablet therapy should be taken by a patient's family member. ${ }^{14}$

Despite the recommendations and counselling addressed to people suffering from malignant diseases, they are continuously facing a number of obstacles, given that despite the need for the constant monitoring of medical therapy (oral or subcutaneous), as well as follow-up examinations that are inevitable for all patients with cancer, there are certain complications that arise due to the impossibility of scheduling follow-up examinations during the pandemic. In order to protect people who are currently receiving cancer treatment from the risks associated with exposure to the virus and to enable the timely receipt of adequate oral therapy, the Association for Fight Against Cancer - BORKA, the Red Cross and the University Clinic for Radiotherapy and Oncology started making daily lists of people living across the country who need medication. Zorica Adzievska, one of the program coordinators for BORKA in Skopje in the past three years, explained the situation that cancer patients are facing during the coronavirus pandemic.

In cooperation with the Red Cross and the University Clinic for Radiotherapy and Oncology, we decided to start making lists of all people who need to deliver medicines to their home. The patients call us, leave data, required therapy and city of residence, and then we forward the list every day. The next day, doctors-oncologists give out a report, and start preparing therapy

\footnotetext{
${ }^{14}$ Ministry of Health "The Clinic for Radiotherapy and Oncology Functions Smoothly During COVID-19 Conditions," (April 11, 2020), http://zdravstvo.gov.mk/klinikata-zaradioterapija-ionkologija-funkcionira-neprecheno-i-vo-uslovi-na-kovid-19-pacientite-da-gipochituvaatpreporakite-za-zashtita-od-koronavirus/?cn-reloaded=1.
} 
for each patient. Then, Red Cross volunteers carry the therapy through the cities. From the beginning of May, we started helping patients in this way, protecting them from travel and reducing their financial costs. On August 8 , we had the largest number of patients, forty three but still, the number varies. In total, only in our country there are 112 registered patients who have been given support with oral therapy-one is sent once, some several times, a new order is made every month, and it is communicated ten days before the delivery so that there is no vacuum. ${ }^{15}$

At present, the country is facing a shortage of medicine due to the protocols for their procurement that takes more time to process, as well as the vast amount of people who are awaiting testing for COVID-19. People are often left without medication for ten days or are forced to take alternative drugs as substitutes because the ones they need are not available, although there must be no interruption in cancer therapy. The current government made a decision to disperse cancer therapy in other cities in the oncology wards so that patients do not travel to Skopje, which is actually part of a larger plan for the successful mobility of doctors across the country. Herein lies another problem that has become more noticeable during the pandemic and that has managed to show all of the implications that an unstable health care system can have, considering that there are not enough medical professionals, especially oncologists in cities across North Macedonia, and more specifically, specialists that treat breast cancer and cancers of women's reproductive organs. Additionally, most of the individuals who are volunteering to help in the process of distributing cancer treatment throughout North Macedonia are women. Currently, there is an ongoing rotation system of specialists in different towns across North Macedonia, in order to prevent people from leaving their homes and towns just so that they can get their regular doctor's appointment in the capital city. The gynaecology department in Kavadarci has already started working in this way. However, some criteria must be met-there are some patients who have to be examined specifically by a specialist, and that cannot always be done in their hometowns, taking into account that the continuity of examinations must not be lost, and therefore cause an unwanted distortion in data and thus diagnosis.

${ }^{15}$ Gala Naseva, "The Battle with Cancer During a Pandemic," PINA (September, 2020), https:// pina. mk/4111-borbata-so-rakot-za-vreme-na-pandemija/.

\section{Conclusion}

The lack of institutional care diminishes the possibility of changing essential social spheres for the benefit of women who are currently suffering the most - the ones who need health treatment and the ones who are still underpaid, yet overworked. In addition, conducting studies that will help understand the reason why the deeply entwined values that perpetually put women in the Balkans on the margins are still incessantly present should be an urgency. The structures that cause the ongoing gendered oppression in all scientific fields, with an emphasis on science, ${ }^{16}$ the same time lack the willpower to create care systems for women on the margins. COVID-19 has managed to open old wounds that keep on reappearing when humanity is at its most vulnerable state, and one of them is the structural and in many ways implicit gender-based discrimination that for once should be perceived as a primary issue, considering that launching a so-called "structural change" strategy that would systematically address all of the issues that are profoundly intertwined with gender inequality that keeps on pushing away long-term alterations and solutions to a global issue is simply not enough. As Caroline Whaley states, "COVID-19 has the potential to be a disaster for equality, ${ }^{17}$ considering that apart from women being the most affected by the pandemic at their workplaces, they are also significantly harmed by the slow but steady return of traditional family norms, if one considers that it is almost impossible to disentangle social regress from a global health crisis. As it is stated in the latest UN report ${ }^{18}$ based on the inevitable impact that COVID-19 has on women, approximately $70 \%$ of the women who live in developing countries are a part of the informal economy. In addition to that, about $70 \%$ of the healthcare workers around the globe are women who are also part of the majority of the medical staff generally have less access to protective equipment, showing that the statistics give us more valuable input than we are eager to read, see or simply accept.

${ }^{6}$ European Commission, "Structural Transformation to Achieve Gender Equality in Science," STAGES (November, 2015), https://eige.europa.eu/sites/default/files/guidelines_stages_5.pd

${ }^{17}$ Maddy Savage, "How Covid-19 is Changing Women's Lives," BBC (July 01, 2020), https://www. bbc.com/worklife/article/20200630-how-covid-19-is-changing-womens-lives.

${ }^{18}$ United Nations, "Policy Brief: The Impact of COVID-19 on Women," ReliefWeb (April 9, 2020), https://reliefweb.int/sites/reliefweb.int/files/resources/policy-brief-the-impact-of-covid-19onwomen-en.pdf. 